\title{
Association between metabolic syndrome and oral health: a bibliographic review
}

\author{
Associação entre síndrome metabólica e saúde bucal: uma revisão bibliográfica
}

Asociación entre el síndrome metabólico y la salud bucal: una revisión bibliográfica

Wilian Reis Rosário1, Antonio Vicente Vieira de Araujo¹, Fernanda Farias Costa1, Ana Cláudia Ribeiro Farias ${ }^{1}$, Milena Sousa Freitas ${ }^{1}$, Ramon Guimarães de Souza ${ }^{2}$, Domingos Magno Santos Pereira $^{1}$, Roberto César Duarte Gondim ${ }^{3}$, Rachel Lamarck ${ }^{1}$, Wermerson Assunção Barroso ${ }^{1 *}$.

\begin{abstract}
Objective: To evaluate the relationship between metabolic syndrome (MS) and oral health. Methods: This is a bibliographic review with articles available in the PubMed, SciELO, Web of Science, Google Scholar and Portal Periódicos databases, published between 2010 and 2020. The keywords used were metabolic syndrome, oral health, obesity, diabetes, hypertension, periodontitis and caries. Results: MS and oral pathologies are some of the biggest health problems in the world today and tend to increase with the development of countries and with the aging of the population. The literature indicates a close relationship between MS and oral health, mainly associating diabetes mellitus (DM) and periodontitis, obesity and dental caries, cardiovascular disease, and periodontitis. Inflammatory factors and diet are important mediators of these relationships. Conclusion: MS and oral health are associated through the mechanisms of inflammation, the immune system, and the diet. MS can reciprocally aggravate dental caries and periodontitis, as well as oral treatment can assist in the treatment of MS, but there are still controversial results and this relationship should be further clarified.
\end{abstract}

Keywords: Metabolic syndrome, Oral health, Periodontitis, Dental caries.

\section{RESUMO}

Objetivo: Avaliar a relação entre síndrome metabólica (SM) e saúde bucal. Métodos: Trata-se de uma revisão bibliográfica com artigos disponíveis nas bases de dados PubMed, SciELO, Web of Science, Google Acadêmico e Portal Periódicos, publicados entre 2010 e 2020. As palavras-chave utilizadas foram síndrome metabólica, saúde bucal, obesidade, diabetes, hipertensão, periodontite e cárie. Resultados: A SM e as patologias bucais são alguns dos maiores problemas de saúde no mundo atualmente e tendem a aumentar com o desenvolvimento dos países e com o envelhecimento da população. A literatura indica uma estreita relação entre SM e saúde bucal, associando principalmente o diabetes mellitus (DM) e periodontite, a obesidade e a cárie dentária, doença cardiovascular e periodontite. Os fatores inflamatórios e a alimentação são importantes mediadores dessas relações. Conclusão: A SM e a saúde bucal estão associadas através dos mecanismos da inflamação, do sistema imunológico e da dieta. A SM pode agravar de forma recíproca a cárie dentária e a periodontite, assim como o tratamento bucal pode auxiliar no tratamento da SM, porém ainda existem resultados controversos e essa relação deve ser mais elucidada.

Palavras-chave: Síndrome metabólica, Saúde bucal, Periodontite, Cárie dentária.

\section{RESUMEN}

Objetivo: Evaluar la relación entre el síndrome metabólico (SM) y la salud bucal. Métodos: Esta es una revisión bibliográfica con artículos disponibles en las bases de datos PubMed, SciELO, Web of Science, Google Scholar y Portal Periódicos, publicados entre 2010 y 2020. Las palabras clave utilizadas fueron

1 Universidade CEUMA, Imperatriz - MA.

*E-mail: wermerson.barroso@yahoo.com

2 Unidade Básica de Saúde Amorim II, Zé Doca - MA.

${ }^{3}$ Faculdade Pitágoras, São Luís - MA. 
síndrome metabólico, salud bucal, obesidad, diabetes, hipertensión, periodontitis y caries. Resultados: La SM y las patologías orales son algunos de los mayores problemas de salud en el mundo actual y tienden a aumentar con el desarrollo de los países y con el envejecimiento de la población. La literatura indica una estrecha relación entre la EM y la salud bucal, principalmente asociando diabetes mellitus (DM) y periodontitis, obesidad y caries dental, enfermedad cardiovascular y periodontitis. Los factores inflamatorios y la dieta son mediadores importantes de estas relaciones. Conclusión: La SM y la salud bucal se asocian a través de los mecanismos de inflamación, el sistema inmunitario y la dieta. La EM puede agravar recíprocamente la caries dental y la periodontitis, así como el tratamiento oral puede ayudar en el tratamiento de la EM, pero todavía hay resultados controvertidos y esta relación debe aclararse más.

Palabras clave: Síndrome metabólico, Salud bucal, Periodontitis, Caries dental.

\section{INTRODUCTION}

The World Health Organization (WHO) defines MS by presence of insulin resistance associated with two or more metabolic abnormalities, such as hyperglycemia, hypertension, hyperlipidemia, obesity, and CVD (WORLD HEALTH ORGANIZATION, 1999).

The increase in the number of cases of obesity and diabetes mellitus verified in recent years has been contributed to growing appearance da MS in the population, associated with high cardiovascular morbidity and mortality and high socioeconomic cost (SCHOLZE J, et al., 2010).

The sedentary lifestyle and bad eating habits are the main factors that influence features measures of obesity, which is defined as a high energy intake from the diet and low caloric expenditure with physical activity. The WHO defined the overweight when the body mass index (BMI) is greater than $25 \mathrm{Kg} / \mathrm{m}^{2}$ and for obesity greater than $30 \mathrm{Kg} / \mathrm{m}^{2}$ (WORLD HEALTH ORGANIZATION, 2020). For the upper-middle socioeconomic class, the fast-foods are more present in the feeding and contributed significantly to obesity, for containing high caloric load and sugary drinks. On the other hand, the lowest socioeconomic class aims more at price than food quality, consuming less fruit, grains and fiber and more carbohydrates, sugary drinks and predominantly fatty and highly processed foods. Thus, obesity is no longer a disease in developed countries (KAUL R, et al., 2018). In 2015 a study in 195 countries defined the global prevalence in 603,7 million obese adults and 107,7 million obese children, pointing out a higher prevalence of obesity for women than for men (AFSHIN A, et al., 2017).

Sedentary lifestyle, bad eating habits, overweight and obesity are risk factors for the development of diabetes mellitus (DM) and MS. In 2019, there were 463 million people with diabetes worldwide, aged between 20 and 79 years. About $80 \%$ these individuals live in developing countries, where the epidemic is most intense and there is increase proportions people affected in younger age groups (INTERNATIONAL DIABETES FEDERATION, 2019).

The WHO characterize the DM as a glucose levels equal to or more than $7.0 \mathrm{mmol} / \mathrm{L}(126 \mathrm{mg} / \mathrm{dL})$ in fasting, glycated hemoglobin $(\mathrm{HbA} 1 \mathrm{C})$ level of $6,5 \%$ as a differentiated diagnosis or that make continuous use of glucose control drugs in the blood (WORLD HEALTH ORGANIZATION, 2016). The type 2 diabetes mellitus (DMT2) developed by obese individuals, is present in $90 \%$ of diabetes cases in worldwide (INTERNATIONAL DIABETES FEDERATION, 2019). In this type, insulin does not promove its funccion properly, characterizing what we call insulin resistance, causing impairment glucose uptake (PETERSMANN A, et al., 2018).

The prevalence of hypertension has increased as an aging of the world population and, mainly, due to in overweigh and obesity increase cases. The hypertension is a cardiovascular disease (CVD) characterized when the systolic pressure is $\geq 140 \mathrm{mmHg}$ and diastolic pressure is $\geq 90 \mathrm{mmHg}$ in the blood vessels, according to the WHO. This morbidity affected 1,13 billion people in the world and represents a stress capable of injury the blood vessel, becoming a risk factor to aneurysm, atherosclerosis, acute myocardial infarction (AMI), stroke and others CVD (WOLRD HEALTH ORGANIZATION, 2013).

It is already rather established what a high quantities sodium diet promote hypertension and increase in pro-inflammatory cytokines, as well as susceptibility to microbial infection (JANTSCH J, et al., 2016). In addition, a rich fatty food diet and poor in vegetables and fruits, excessive use of alcohol, routine stress, and 
physical inactivity are also risk factors to hypertension development (WOLRD HEALTH ORGANIZATION, 2013).

The advent of technology brought greater convenience in daily life, such as ordering and delivering food to the user home and requesting instant means of transport. This comfort and practicality significantly affect in the sedentary lifestyle, increase the physical inactivity and bad eating habits. The diet is a common risk factor between MS and the oral health damage, enabling a higher incidence and prevalence both in metabolic disorders that make up MS and in pathologies oral, such as dental plaque, tooth decay or periodontitis (KAUL R, et al., 2018).

At the beginning accumulation of supra-gingival plaque there is a predominance of microorganism associated with health. However, during time and without eliminating this biofilm, there is the establishment of the first inflammatory response, which is diagnosed as gingivitis. Consequently, it is possible observe a significant increase of bacteria with great pathogenic potential in the supra and subgingival biofilm. If the biofilm accumulation condition is maintained, there is an increase in the inflammatory response, reflecting in worsening in the clinical periodontal indicators, which in the susceptible individuals, may progress to periodontitis (MARSH PD, et al., 2011).

Periodontitis is a gum inflammatory process which destroys the jawbone, promoted by an imbalance in the oral cavity microbiota, caused by a host response to bacteria in the dental biofilm. If the inflammatory agent persists, the destruction of these structure results in weakening and decreased support, tooth and, eventually tooth loss (VERHULST M, et al., 2019). The risk factors of the periodontal disease are divided between those that can be modified, such as smoking, diabetes mellitus, obesity, alcoholism, osteoporosis, and stress, and those that cannot be modified, such as genre, ethnicity, age, and genetic factors (HONG M, et al., 2016).

In the Global Burden of Disease study, in 2015, the worldwide prevalence of untreated caries was 2,5 billion people (KASSEBAUM NJ, et al., 2017). The tooth decay is a multifactorial, communicable and the highly prevalent disease worldwide. The main cause of the disease occurs through formation of a biofilm by normal microbiota of the oral cavity through the fermentation of carbohydrates from food. This fermentation produces acids which reduce the $\mathrm{pH}$ and demineralizes the tooth tissue, such as dentin and enamel.

In addition, immunological factors, genetics, environmental and lifestyle can collaborate to development of this pathology. The treatment plan must be individual for each patient, evaluating dental caries activity and personal risk. The mechanical treatment of plaque, dietary reeducation with partial restriction of sugary food and saliva stimulation to neutralize $\mathrm{pH}$ can contribute to prevention and treatment of this disease (SANZ M, et al., 2017).

The metabolic dysfunctions that make up MS cause a systemic and exacerbate inflammatory state, which provides the patient a great vulnerability to infection by pathogens and predispose the progression of periodontal disease. In addition, the risk factors are also shared between oral health and MS, mainly related to bad eating habits. Thus, the objective of this study was to carry out a bibliographic review on the relationship of the metabolic syndrome with changes in oral health and the associated risk factors.

\section{METHODS}

In the bibliographic review, we searcher for index articles available in electronic databases PubMed, Scientific Electronic Library Online (SciELO), Institutional Repository For Information Sharing (IRIS), Web of Science and Portal Journals, published in Spanish and English, between 2010 and 2020. The keywords used were the following: metabolic syndrome, oral health, obesity, diabetes, hypertension, periodontitis, tooth cavity and plaque. The inclusion criteria applied were articles, global reports and original these published in electronic databases between the years 2010 and 2020, with exception of SM definition reference by WHO in 1999 . We also use websites with update data from World Health Organization.

The exclusion criteria applied were reports published before 2010, gray literature information, such as Wikipedia, and unofficial websites. In the end, 93 articles were selected in this survey for reading and analysis, 
using a total of 28 articles chosen to carry out this report. We access the full text of all relevant references from the search results. The stages of the bibliographic reference selection process are represented in Figure 1.

Figure 1 - Stages of the bibliographic reference selection process.
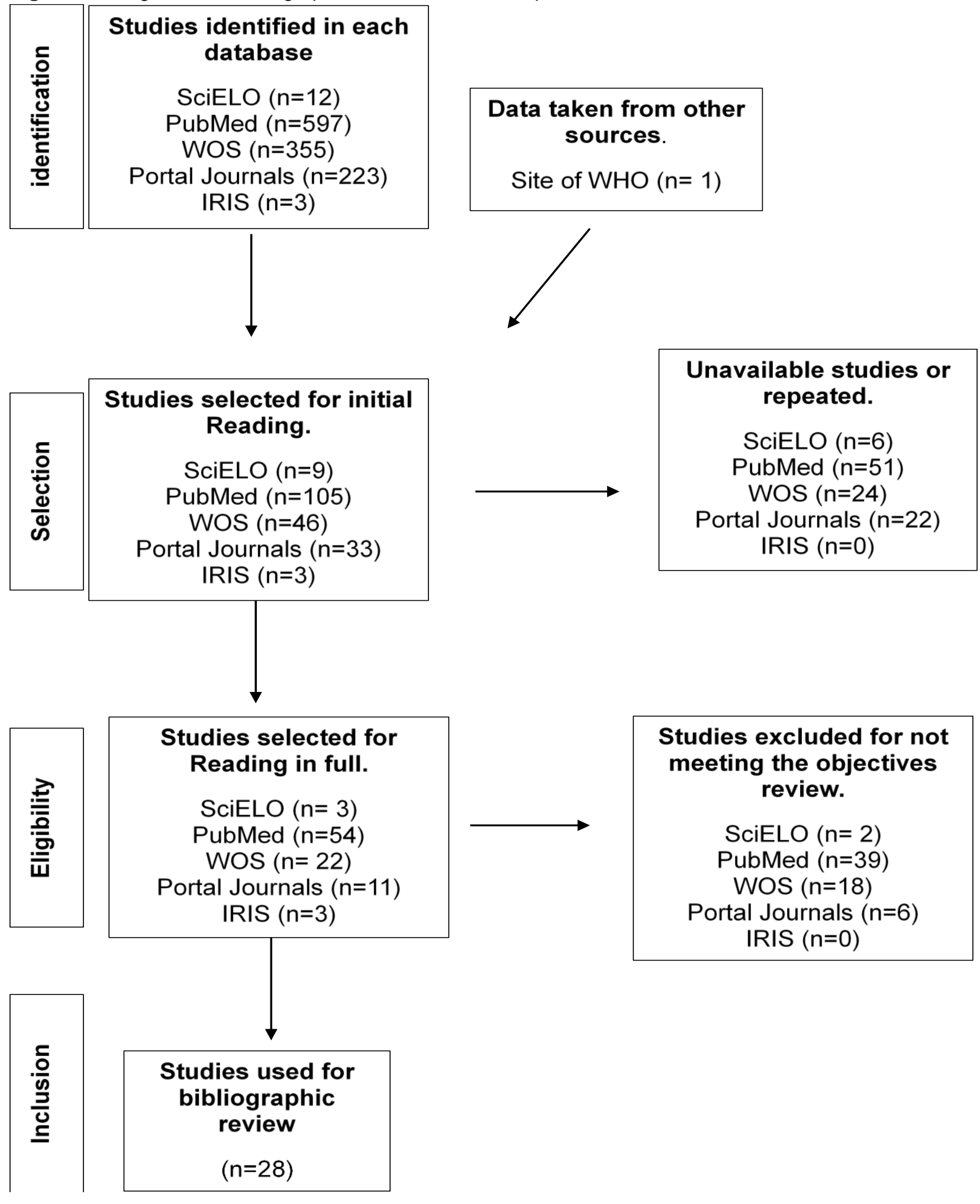

Source: ROSÁRIO WR, et al., 2020. 


\section{RESULTS AND DISCUSSION}

The prevalence of chronic diseases increases as countries develop, phenomenal called epidemiological transition. From 1990 to 2015 oral diseases ranked among the 10 mainly causes of years live with disability (YLDs) and the CVDs continued to be a leading cause of years of life lost due to premature or disability death (YLLs) in global public health (DYE BA, 2017).

The number of people with oral problems in 2015 was 3.5 billion people. Of his total, untreated caries in permanent teeth represented $71,42 \%$ (2,5 billion people), the untreated caries in primary teeth, severe periodontal disease and the total teeth loss affected $16,38 \%, 15,38 \%$ and $7,89 \%$ respectively (KASSEBAUM $\mathrm{NJ}$, et al., 2017). The untreated dental caries in permanent teeth represent a predominant portion of prevalent cases in global public health, regardless of socioeconomic class, followed of periodontal disease (DYE BA, 2017). The worldwide economic cost of direct treatment to oral disorders is estimated in US $\$ 298$ billion per year (LISTL S, et al., 2015).

The growing sedentary habit, the frequent or abundant consumption of highly processed and high sugar food, can increase the risk of weight gain and obesity. It is assumed that the longer contact time of teeth with these foods may increase risk to development of dental caries. However, energy balance can be achieved with frequent physical activity and regular oral hygiene can decrease a dental caries risk (LI LW, et al., 2018).

A retrospective cohort study using data from the National Health Insurance Research Database of Taiwan compared the risk of development of atrial fibrillation (AF) between 460.597 patients with periodontal disease and 668.101 individuals in the group without periodontal disease. It found that the group with periodontal disease had a $31 \%$ higher risk to development AF than those without periodontal disease. In addition, there was a statistically positive association between periodontal disease and risk of AF for heart failure, hypertension, DM, vascular disease, hyperlipidemia, ischemic heart disease, valve heart disease, chronic obstructive pulmonary disease, kidney disease and hypothyroidism (CHEN DY, et al., 2016).

One study shows that there is a close relationship between obesity, metabolic syndrome and changes in the oral environment in children and adolescents. Obesity significantly increases the incidence of dental disease of the hard tissues, periodontal diseases and the stomatognathic system, as well also affecting the secretion activity of the salivary glands (HAYDEN C, et al., 2013).

The study by Kaul R et al. (2018) showed a positive association between dental caries and childhood obesity. Children between 6 and 12 years old, who no longer had their diet as controlled by their parents, showed that those with overweight and obesity had better oral hygiene compared to individuals with low weight or normal weight. However, a higher average index of primary and permanents teeth affected by caries was observed in the children with overweight and obesity, with as relationship between $\mathrm{BMI}$ and dental caries index, regardless of oral hygiene.

Another study compared the periodontal damage between people with $\mathrm{BMI}>30 \mathrm{Kg} / \mathrm{m}^{2}$ and $\mathrm{BMI}<30 \mathrm{Kg} / \mathrm{m}^{2}$, with a mean age of 34 years. As a result, obese people had average gingival index (GI) probing depth (PD) gingival recession and clinical insertion level of $33.84 \%, 28.59 \%, 24.44 \%$ and $21.21 \%$ respectively, higher rates in relation to non-obese individuals, pointing a relationship between obesity and impaired oral health. However, the mechanism of influence of obesity on oral health is not clear yet (DESHPANDE NC e AMRUTIYA $M R, 2017)$.

The results of one study show that periodontitis correlated with the obesity and hyperglycemia, in consideration of others risk factors, suggesting a direct causal relationship between periodontitis and these metabolic changes. The study was carried in Japanese, adults, female and male employee aged between 20 and 59 years. It was revealed that individual's component of MS, including obesity, hypertension, lipid abnormalities, hyperglycemia, were associated with periodontal disease.

In addition, the study noted that the presence of periodontal pockets associated with positive conversion of one or more components of MS, since blood arterial pressure and blood lipid index correlated with presence of periodontal pockets. Still, it was reported that individuals with MS, had periodontal conditions significantly worse than healthy participants. However, in this study the lipid abnormalities and hypertension did not correlate with periodontitis (SAKURAI SI, et al., 2019). 
The hyperglycemia increases the levels of diverse cytokines and mediators in saliva and in the gingival crevicular fluid (GCF), as well promote oxidative stress of periodontal tissues and forming the advanced glycation end products (AGEs). The interaction of AGEs with their receptors in polymorphonuclear and mononuclear cells block the chemotaxis and the phagocytosis mechanism of these cells, conditioning a favorable environment for the proliferation of gram-negative bacteria. From this process, the sensitivity to bacterial antigens by macrophages increases and releases inflammatory cytokines promoting an increase inflammatory response and the destruction of periodontal tissue, whereas periodontitis promotes systemic oxidative stress and increase levels of $C$ reactive protein, which provide diabetes complications (CHAPPLE ILC e GENCO R, 2013).

One study of 92 patients with DMT2, perform a mechanical remove of supra and subgingival bacterial plaque in 46 individuals with scarpers. In the group that receive treatment with antibiotic and/or root canal, when necessary, a reduce in means levels of glycated hemoglobin A1c $(\mathrm{HbA1c})$ was observed $10,5 \%$ over a period of six months and decrease in the difficult of glycemic control, whereas in the group that did not receive these treatment there were no change in these levels. The early diagnosis of DM and interdisciplinary intervention are important so that problems caused by this disease are avoided, as well the knowledge of oral changes to diagnosis in these patients. The management of periodontitis is very important in people with diabetes and the ideal oral hygiene may prevent the tooth loss and improve glucose control (SALMAN S, et al., 2016).

In one study the periodontitis prevalence in the individuals with DM was $43,7 \%$, while in individuals without DM it was $25 \%$ (HONG M, et al., 2016). There was also a relationship between the presence of metabolic and periodontal disease in $69,2 \%$ of patients. The diabetic women $(46,4 \%)$ had a higher periodontal disease rate, than male diabetics patients (23\%). The periodontitis was the predominant condition, represented by $57,4 \%$ of patients, following to chronic gingivitis with $31,5 \%$. The presence of calculus, oral hygiene deficient and lack of teeth were a factor that occurred most frequently, with $74,4 \%, 66,7 \%$, and $48,7 \%$ respectively. The number of patients who presented glycemic values within the normal parameter increase after periodontal treatment from $48,5 \%$ to $89,6 \%$, while those with hyperglycemia decrease $40 \%$ (PITA MM, et al., 2019).

Another study carried out in the Netherlands shows that the oral health problems are relatively commons in patients with DM2. The research was conducted on 764 patients with DM2, 82\% of whom suffered from at least one of the following oral health problems: pain in the mouth, dry mouth, bad breath and periodontitis. Almost $11 \%$ of the patients were metabolically poorly controlled, $39 \%$ were obese, $37 \%$ had hypertension and $44 \%$ had dyslipidemia. About a quarter (24\%) related not visiting a dentist regularly and $30 \%$ did not have dental insurance coverage.

In addition, $16 \%$ of patients were edentulous and with complete dental prosthesis, while $29 \%$ had partial dentures. Pain in the mouth, dry mouth and bad breath were reported by $15 \%, 37 \%$, and $12 \%$ of patients, respectively. Almost $70 \%$ suffered of periodontitis. The quality of life related with oral health was impaired in $19 \%$ of patients, who also had worse overall quality of life related with health (VERHULST M, et al., 2019).

The inflammatory state resultant from metabolic disorders contributes to the forming of a pro-inflammatory environment, with increase of cytokines IL-1 $\beta$ and IL-6, in the periodontium. Diabetics patients also have elevated levels of IL-1 $\beta$ and IL- 6 in the gingival crevicular fluid (GCF). The human gingival fibroblasts (HGF) are the predominant cells in periodontal connective tissues and act in gingival healing by regulating the production of matrix metalloproteinases (MMPs) which are enzymes responsible by destruction of the extracellular matrix, such a collagen. It is assumed that the cytokines IL- $1 \beta$ and IL- 6 can change the amount of MMPs in the HGF, being responsible for tissue destruction through the change in collagen production, disrupting the healing process of lesions.

In a clinical study, progression of periodontitis was observed significantly in patients with DM compared patients without DM. It has already been observed in vitro that levels of glucose can stimulate IL- $1 \beta$ and IL- 6 through macrophages in inflammatory periodontal tissues, and together they can aggravate periodontal destruction through the production of MMPs by HGFs (LEW JH, et al., 2018). 
In the insulin receptor substrate-1 (IRS-1) there are several serine phosphorylation sites that can be activated through multiple cytokines, such as IL-1, IL-6 and TNF-a, from the activation of several serines kinases, resulting in a decrease in the binding of the insulin receptor with its substrate and, consequently, promoting insulin resistance (SHIBATA T, et al., 2013). In addition, these inflammatory mediators modulate the receptor activator of nuclear factor-kappa $B$ ligand (RANKL) which is directly involved in the increase of osteoclastogenesis, stimulating bone resorption, destroying bone tissue and contributing to the progression of periodontitis (ZHAl ZJ, et al., 2014).

Table 1 show directly and concisely the different mechanisms of relationship between different morbidities of the metabolic syndrome with end oral health. It is noted that the inflammatory state between DM and periodontitis stimulated both pathologies, more quickly worsening the patient health status. On the other hand, the diet is a prevalent and common factor between obesity and tooth decay.

Table 1 - Mechanisms of relationship between metabolic disorders and oral health.

\begin{tabular}{|c|c|c|}
\hline Pathologies & Mechanisms & References \\
\hline $\begin{array}{l}\text { CVD and } \\
\text { periodontitis }\end{array}$ & $\begin{array}{l}\text { Systemic inflammation, electrical and structural } \\
\text { remodeling of the atrium and infiltration of atrial } \\
\text { lymphomononuclear cells. }\end{array}$ & (CHEN DY, et al., 2016). \\
\hline $\begin{array}{l}\text { Diabetes Mellitus } \\
\text { and periodontitis. }\end{array}$ & $\begin{array}{l}\text { Advanced glycation products resulting from } \\
\text { hyperglycemia, lead to the activation of macrophages, } \\
\text { producing inflammatory cytokines and reactive oxygen } \\
\text { species, which increase the destruction of soft and } \\
\text { hard tissues. }\end{array}$ & (HONG M, et al., 2016) \\
\hline $\begin{array}{l}\text { Diabetes Mellitus } \\
\text { and periodontitis. }\end{array}$ & $\begin{array}{l}\text { Behavioral factors favor the aggressiveness of } \\
\text { microorganisms in the destruction of the periodontium. }\end{array}$ & (PITA MM, et al., 2019) \\
\hline $\begin{array}{l}\text { Diabetes Mellitus } \\
\text { and periodontitis. }\end{array}$ & $\begin{array}{l}\text { High glucose can stimulate IL-1 } 1 \text {, IL- } 6 \text { and sIL-6R } \\
\text { attack HGF by unbalancing the balance of MMPs and } \\
\text { MMPI, leading to the destruction of periodontal tissue. }\end{array}$ & (LEW JH, et al., 2018). \\
\hline $\begin{array}{l}\text { Obesity and } \\
\text { dental caries. }\end{array}$ & $\begin{array}{c}\text { Intake of carbohydrates and sugary foods more } \\
\text { frequently was a common risk factor between obesity } \\
\text { and tooth decay. Increasing calorie consumption and } \\
\text { prolonged tooth exposure time with food. }\end{array}$ & $\begin{array}{c}\text { (HAYDEN C, et al., } \\
\text { 2013) }\end{array}$ \\
\hline $\begin{array}{l}\text { Obesity and } \\
\text { dental caries. }\end{array}$ & $\begin{array}{l}\text { Biofilm formation by carbohydrate fermentation } \\
\text { reduces the } \mathrm{pH} \text { through the formation of acids that } \\
\text { destroy tooth enamel and dentin. }\end{array}$ & (KAUL R, et al., 2018) \\
\hline $\begin{array}{l}\text { Metabolic } \\
\text { syndrome and } \\
\text { periodontitis }\end{array}$ & $\begin{array}{c}\text { TNF- } \alpha \text { induces the release of C-reactive protein and } \\
\text { fibrinogen increasing the existing inflammatory } \\
\text { response. }\end{array}$ & $\begin{array}{c}\text { (SAKURAI SI, et al., } \\
2019)\end{array}$ \\
\hline $\begin{array}{l}\text { Diabetes Mellitus } \\
\text { and oral health }\end{array}$ & $\begin{array}{l}\text { Inflammatory response to fight bacteria in dental } \\
\text { biofilm also affected patients' periodontal tissue. }\end{array}$ & $\begin{array}{l}\text { (VERHULST M, et al., } \\
\text { 2019) }\end{array}$ \\
\hline
\end{tabular}

Subtitle: CDV: Cardiovascular diseases; HGF: Human gingival fibroblasts; IL-1 $\beta$ : Interleukin-1 $\beta$; IL-6: Interleukin-6; sIL-6R: Soluble IL-6 receptor; MMPs: Matrix metallopeptidases; MMPI: matrix metalloproteinase inhibitor (MMPI); TNF-a: Tumor necrosis fator- $\alpha$.

Source: ROSÁRIO WR, et al., 2020.

\section{FINAL CONSIDERATIONS}

Patients with MS have more complications and impaired oral health status, especially patients with DM. In diabetic patients, destruction of periodontal tissue hinders glycemic control, increase insulin resistance, decrease the patient's immune defenses and periodontal tissue restoration. Among oral pathologies, periodontitis is more related to the comorbidities of the metabolic syndrome, sharing inflammatory pathways in common, especially with DM, where the bidirectional relationship between these two pathologies is more clarified in the literature when compared to other morbidities. Treatment of periodontitis improves glucose levels. TNF- $\alpha$ is the main inflammatory mediator that relates MS and periodontitis, acting on the destruction of periodontal tissue and on cellular insulin receptors, reducing glucose uptake. The cytokines IL-1 $\beta$ and IL- 6 can change the amount of MMPs in the HGF causing problems in healing periodontal tissue. Caries is more related 
to the lack of oral hygiene and the food consumed, being related to a common risk factor and not to obesity itself. Although obesity was not directly associated with periodontitis, it must be considered that this morbidity contributes to a worse glycemic control, in addition to increasing circulating inflammatory mediators. There is still no clear link in the studies that associate CVD and oral pathologies. Patients with periodontitis must undergo a multiprofessional evaluation for better glycemic control and visceral fat, in order to obtain a better quality of life. Further studies need to be done to specifically clarify how oral health is influenced by MS or any of its comorbidities.

\section{REFERENCES}

1. AFSHIN A, et al. Health Effects of Overweight and Obesity in 195 Countries over 25 Years. New England Journal of Medicine, 2017; 377(1): 13-27.

2. CHAPPLE ILC, GENCO R. Diabetes and periodontal diseases: consensus report of the Joint EFP/AAP Workshop on Periodontitis and Systemic Diseases. Journal of Clinical Periodontology, 2013; 40(14): 106-112.

3. CHEN DY, et al. Risk of Atrial Fibrillation or Flutter Associated with Periodontitis: A Nationwide, Population-Based, Cohort Study. PLOS ONE, 2016; 11(10): 01-14.

4. DESHPANDE NC, AMRUTIYA MR. Obesity and oral health - Is there a link? An observational study. Journal of Indian Society of Periodontology, 2017; 21(3): 229-233.

5. DYE BA. The Global Burden of Oral Disease: Research and Public Health Significance. Journal of Dental Research, 2017; 96(4): 361-363.

6. HAYDEN C, et al. Obesity and dental caries in children: A systematic review and meta-analysis. Community Dentistry and Oral Epidemiology, 2013; 41(4): 289-308.

7. HONG M, et al. Prevalence and risk factors of periodontitis among adults with or without diabetes mellitus. The Korean Journal Internal Medicine, 2016; 31(5): 910-919.

8. INTERNATIONAL DIABETES FEDERATION. IDF Diabetes Atlas. International Diabetes Federation. $9^{\mathrm{a}}$ ed. Brussels, Belgium: International Diabetes Federation, 2019.

9. JANTSCH J, et al. Cutaneous $\mathrm{Na}+$ storage strengthens the antimicrobial barrier function of the skin and boosts macrophagedriven host defense. Physiology \& behavior, 2016; 176(1): 139-148.

10. KASSEBAUM NJ, et al. Global, Regional, and National Prevalence, Incidence, and Disability-Adjusted Life Years for Oral Conditions for 195 Countries, 1990-2015: A Systematic Analysis for the Global Burden of Diseases, Injuries, and Risk Factors. Journal of Dental Research, 2017; 96(4): 380-387.

11. KAUL R, et al. Association between Obesity and Oral Health Status in Schoolchildren: A Survey in Five Districts of West Bengal, India. International Journal of Clinical Pediatric Dentistry, 2018; 11(3): 233-237

12. LEW JH, et al. High Glucose-Mediated Cytokine Regulation in Gingival Fibroblasts and THP-1 Macrophage: a Possible Mechanism of Severe Periodontitis with Diabetes. Cellular Physiology and Biochemistry, 2018; 50(3): 973-986.

13. LI LW, et al. Caries-related risk factors of obesity among 18-year-old adolescents in Hong Kong: a cross-sectional study nested in a cohort study. BMC Oral Health, 2018; 18(1): 188-200.

14. LISTL S, et al. Global economic impact of dental diseases. Journal of Dental Research, 2015; 94(10): $1355-1361$.

15. MARSH PD, et al. Dental plaque biofilms: communities, conflict and control. Periodontology 2000, 2011; 55(1): 16-35.

16. PITA MM, et al. Estado periodontal en pacientes diabéticos. Revista de Ciencias Médicas de Pinar del Río, 2019; 23(5): 705-715.

17. PETERSMANN A, et al. Definition, Classification and Diagnosis of Diabetes Mellitus. Experimental and Clinical Endocrinology \& Diabetes, 2018; 126(07): 406-410.

18. SAKURAI SI, et al. A longitudinal study on the relationship between dental health and metabolic syndrome in Japan. Journal of Periodontology, 2019; $90(7):$ 728-746.

19. SALMAN S, et al. Effect Of Non- Surgical Periodontal Treatment On Glycemic Control Among Type 2 Diabetes Mellitus Patients With Periodontitis. Journal of Ayub Medical College, Abbottabad: JAMC, 2016; 28(4): 442-445.

20. SANZ M, et al. Role of microbial biofilms in the maintenance of oral health and in the development of dental caries and periodontal diseases. Consensus report of group 1 of the Joint EFP/ORCA workshop on the boundaries between caries and periodontal disease. Journal of Clinical Periodontology, 2017; 44(18) 5-11.

21. SCHOLZE J, et al. Epidemiological and economic burden of metabolic syndrome and its consequences in patients with hypertension in Germany, Spain and Italy; A prevalence-based model. BMC Public Health, 2010; 10(1): 529-541.

22. SHIBATA T, et al. Inhibition of the TNF-a-induced serine phosphorylation of IRS-1 at 636/639 by AICAR. J Pharmacol Sci, 2013; 122(2): 93-102.

23. VERHULST M, et al. Self-reported oral health and quality of life in patients with type 2 diabetes mellitus in primary care: a multi-center cross-sectional tudy. Diabetes, Metabolic Syndrome and Obesity: Targets and Therapy, 2019; $12: 883-899$.

24. WORLD HEALTH ORGANIZATION. Definition, diagnosis and classification of diabetes mellitus and its complications: Report of a WHO consultation. World Health Organization. Geneve; 1999.

25. WORLD HEALTH ORGANIZATION. Global Report on Diabetes. World Health Organization. Geneva. 2016.

26. WORLD HEALTH ORGANIZATION. An overview of hypertension around the world: a disease that kills in silence, a global public health crisis: World Health Day 2013. World Health Organization. Geneva. 2013.

27. WORLD HEALTH ORGANIZATION. Obesidade. 2020. Disponível em: <https://www.who.int/news-room/factsheets/detail/obesity-and-overweight>. Acesso em: 23 MAIO. 2020.

28. ZHAI ZJ, et al. Andrographolide suprime a osteoclastogênese induzida por RANKL in vitro e previne a perda óssea inflamatória in vivo. Br J Pharmacol, 2014; 171(3): 663-675. 